\title{
Rationality and Human Fulfilment Clarified by a Thomistic Metaphysics of Participation
}

\author{
ANDY MULLINS \\ University of Notre Dame Australia \\ apjm.vic@gmail.com \\ ORCID: 0000-0003-1540-3796
}

\begin{abstract}
A Thomistic metaphysics of participation in being offers an account of rationality that is more complete and coherent than that of nonreductive physicalism. It is a reasoned understanding of how an embodied intellectual subject shares in being and intellectual life. This metaphysical framework supports an understanding of rationality as a participated power, and an essential property of human nature empowering persons to know reality and make choices accordingly. Human fulfilment in truth and love is a consequence of the grounding of the transcendentals of truth and goodness in being. In contrast, nonreductive physicalism reduces rationality to processes and subjective experiences and can offer no priority between human material and spiritual fulfilment. Although a Thomistic metaphysics of participation in being has been effectively absent from Anglo-American hylomorphic philosophy of mind, this paper suggests it is time to reassess the benefits it offers.
\end{abstract}

Keywords: teleology, hylomorphism, philosophy of mind, Aquinas, nonreductive physicalism.

\footnotetext{
Abbreviations for the works of St. Thomas Aquinas

DE - De ente et essentia

DP - De potentia Dei

DSS - De substantiis separantis

QDdA - Quaestiones disputatae de anima
} 
QDdV - Quaestiones disputatae de veritate

SCG - Summa contra gentiles

ST - Summa theologiae

\section{Rationality and human fulfilment}

Over the past thirty years that correspond to dramatic developments in the capacity of science to investigate the brain in real time, it has become clear that physical structures, processes and systems are indeed implicated in all aspects of mental life. We now know, for example, that memory is encoded throughout the brain, that there are centres of the brain implicated in moral choices, that conditioned learning in fear responses and pleasure pathways play a role in habit formation in response to pain and pleasure, that there are pathways between the emotional centres of the brain and the cognitive centres where emotional impulses may be "processed". (Graybiel \& Smith 2014; Mroz 2018; Mullins 2016; Pontifical Academy of Sciences 2012)

Largely in response to mounting neural evidence, nonreductive physicalism (NRP) in its many forms, has taken centre stage. NRP holds that the mental domain of human experience coexists with the physical but may not be reduced to it. It has been criticised by dualists (Chalmers, 1996) and by hardcore reductive materialists (Van Gulick 2001). Kim argues that NRP is an oxymoron: "If nonreductive physicalists accept the closure of the physical domain, they have no visible way of accounting for the possibility of psychophysical causation." (Kim 1989, 47). His critique of NRP has been described as "remarkably effective" (Murphy 2009, 2). Wilson suggests that Kim's argumentation has not yet been successfully challenged even by advocates of weak emergence. Knowles has observed that NRP solutions seem non-necessary and "arbitrary" $(1999,181)$. Horvat (2017) notes the challenge of preserving unity of the person, and a further debate centres on free will: see for example Leite's 2018 refutation of Gazzaniga's arguments against neuro-cognitive reductionism.

In response advocates of NRP seek to preserve unity of the agent: either by affirming the subjective life of the agent and ignoring the neurophysical (Scruton 2012), or by searching for mechanisms of causality, 
exemplified by Nancey Murphy (1998) and the general direction of Justin Tiehen's work (cf 2019).

At the heart of NRP is an a priori rejection not only of dualism but of metaphysics. Nancey Murphy states, "it is not necessary to postulate a second metaphysical entity, the soul or mind, to account for human capacities and distinctiveness" (Murphy 1998, 2). Roger Scruton's approach was to bypass the biophysical, offering an understanding of rationality reduced to subjective states or to processes: "First-person awareness and practical reason (the giving and taking of reasons for action) are the forces that shape the human person. These forces are, I maintain, unaffected by the proof that our actions, thoughts, and perceptions are dependent on a vast machinery of brain processes of which we are not aware" (Scruton 2014, 76). Yet in 2012 Roger Scruton himself wrote in personal correspondence with the author of this paper: "In the end we need some kind of teleological metaphysics to make sense of our condition."

A Thomistic metaphysics appears to provide a key (for example, Jeffreys 2005; Tabaczek 2016, Oleksowicz 2018). In this paper I suggest specifically that a Thomistic metaphysics of participation (TMP) allows an account of mental life that permits freedom and rationality, demonstrating that human happiness lies in realising the ends of rationality - understanding and love-choices as essential operations of a human being.

\subsection{The importance of an adequate rationality}

Evolutionary anthropology, ethics, and epistemology are battlegrounds of ideas and there is little agreement about a term such as "rationality". Rather than be diverted into this highly contested field, for this paper I will adopt from common usage of the term, "rationality" as understood as the point of specific difference between homo sapiens, and animals. It is the approach Aquinas took defining human being as a "rational animal" (ST, $\mathrm{I}^{\mathrm{a}}$, q. 75, a. 3). This does not mean that all humans are rational at every point in time, just as "biped" does not mean all human beings actually have two legs.

TMP holds that rationality is an essential property of human nature whereby we can know reality and be self-directing, loving, (albeit with 
many constraints) on the basis of that knowledge. These capacities for knowing and loving reveal themselves as essential properties of a human being with teleological implications for realist fulfilment.

\subsection{The approach of this paper}

TMP offers an account of mental life that is more coherent and more complete than can NRP. It accommodates the benefits of a physicalist account, in offering an understanding of embodied human nature, where neurobiology clearly is a condition of mental life. NRP however, because of its physicalist origins, lacks clarity about teleological implications, limits rationality to processes and subjective experiences, and severs the intrinsic connection of rationality to human nature.

First, I suggest TMP is more coherent than NRP because, arguing from contingency, rationality must be understood as an essential property of human nature, a property that, through the transcendental convertibility of truth and goodness, is in act through the same actus essendi by which the person exists, by participation in subsistent being. By this paradigm of participation TMP presents a coherent argument that rationality and being of the subject are both grounded in, to use the terminology of Norris Clarke, the Being of the Infinite Source, "who alone possesses this perfection in unlimited intensive plenitude as pure Subsistent Act of Existence" (1995, 12-13). Hence, although NRP can only present rationality as characterized by certain behaviours and processes that somehow seem broadly descriptive of human nature, TMP offers a reasoned account whereby rationality is an essential human property.

Second, the account of TMP is more complete because it tells us more about human beings. As rationality is shown to be an essential property of human nature, if it is exercised appropriately in its operations of knowing and choosing, then it is directly causal of fulfilment of the human subject. In contrast I argue that advocates of NRP can offer little clarity on the issue of human fulfilment.

Finally, I offer an understanding of human fulfilment demonstrably intrinsic to human nature. 


\section{A greater coherence in the account of rationality}

\subsection{A valid Thomistic approach}

Aquinas affirms that, in this embodied life, biophysiology is implicated in all rational operations: "intellectual knowledge is caused by the senses.... it is in a way the material cause (ST, $\mathrm{I}^{\mathrm{a}}, \mathrm{q}$. 84, a. 6)". I suggest this is a valid reading of Aquinas based on his statements, of which those below are typical, on his views on agency of the embodied person, and on his presentation of the active intellect as a participated power.

I propose that immaterial operations of rationality can be validly understood as transcendent operations carried out by ensouled matter through a participated power. They are not the work of a ghostly substance, or some wholly inherent property shrouded in mystery and supported by assertion. Thus substance dualism is avoided and the quantity of evidence accruing from neuroscience is satisfied.

I am conscious that advocates of hylomorphism have differing views of immateriality - for example Robert Pasnau (1998) has argued that the standard hylomorphic account confuses ontological and representational immateriality. However, my position is that "immateriality of thought" refers to the operation of thought present in ensouled matter.

By Aquinas' account immaterial and intelligible species are produced by the active intellect as a result of a "Divine light" (ST, I $\mathrm{I}^{\mathrm{a}}$, q. 89, a. 1). The intellect is a "participated power" because of this "Divine light", which is a power not properly its own, but one which "belongs to another fully" (Aquinas Expositio 1.2, cited in Fabro 1974, 454). Just as the soul is a participation in Being, transcending matter but within matter, so immaterial species are present by participation.

Aquinas writes of "operations", not structures nor physical representations (SCG, 2, 90,4). These rational operations are conducted in the physical, but may not be reduced to physical processes. However, there is no other agent than the embodied, ensouled person. 
It can be said that the soul understands ... but it is said more properly that the human being understands through the soul. ST, I' , q. 75, a. 2.

Aquinas' insight is that all things participate in subsisting Being, and this universal ground of being bestows a grand coherence on the hylomorphic notions of Aristotle - matter and form, the four causes, act and potency, and hierarchy of being - according them an explanatory force that accepts the role of neurobiological bases in all mental operations. Although beyond the scope of this paper, truth understood as a participation also provides a compatible account for how the human soul, after dissociation from the body, can still know, by participation in Divine ideas (ST, III ${ }^{\mathrm{a}}$, q. 79 , a. 2, ad.3).

\subsection{Necessity of a metaphysics of participation}

The argument from contingency is central to the demonstration of the necessity of participation in being for embodied rational subjects. It starts with the observation that existence and essence are distinct notions: "I can understand what a man is, or what a phoenix is, and yet not know whether they have existence in the real world (DE, III, 77)". Embodied rational subjects come into embodied existence and pass out of embodied existence. Matter may perdure but this is not so for intellectual subjects, persons. Before conception, the person is absent, after death the embodied person, the agent, has departed.

To explain life, Aristotle postulated that the animal soul emerges from matter and so animate beings have life. This argument however cannot be applied to human beings. Because human beings have intellectual capacities that exceed the possibilities of matter: they have the capacity to know non-material realities, and they have freewill. Aquinas argued that something exclusively physical cannot account for intellectual life: "the greater is not brought about by the lesser, for nothing acts outside its species". (ST, III", q. 79, a. 2); "no corporeal power can produce the intellective soul" (SCG, 2, 86, 7).

The human soul is understood by Aquinas as the principle of being, life and function, the principle of personhood, the formal principle but 
also actus essendi. Not arising from matter, yet ensouling a substance subject to contingency, this principle must be understood as something bestowed from outside matter, a participation in existence and rationality. It is necessary to postulate an Infinite Source in order to explain the reality of actual existence.

It is clear, therefore, that the intelligences are form and existence and have existence from the first being, which is existence alone, and this is the first cause, which is God. DE, III, 80.

The Thomistic position is that participation in being of an essence is limited by the essence. In human nature, the soul is the animating principle, limited by the human essence. It is also the principle of act of essential perfections, the operations of rationality. That the existence of an intellectual being is directly dependent upon participated being, as something shared or as gift, bestows on the subject and its rationality a profound dignity. This profound dignity is a major point of difference from the rationality discussed by NRP.

In contrast with Aristotelian hylomorphic accounts, and Thomistic approaches that do not embrace participation (Feser 2005; Madden 2013; De Haan, 2018), a framework of Thomistic participation ensures that existence is prior, not by assertion but by explicit metaphysical demonstration. The objectivity of reality and causality are more easily lost when existence is not respected as prior because the being, knowing, and loving (operating with personal agency) of a human subject would lose their integral convertibility at their transcendent foundations through participation in ipsum esse subsistens. Participation is a sharing in some way in the esse of an Infinite Source.

Although Aristotle had been somewhat dismissive of Plato's idea of participation in forms (Aristotle Metaphysics, 8, 6), Aquinas adopted the Neoplatonic notion of participation because through it he was able to explain that essence and existence are really distinct, and crucially, he applied the notion of act and potency to being, giving primacy to the act of being (Rziha 2009, 7). He presented esse as actus essendi 'the total de- 
pendence of the creature on its Creator', in contrast to existentia of Augustinianism and of rationalism (Fabro 1974, 449), and presented form not only as a principle of function or unity, but as a participation in esse subsistens (Fabro 1970, 71-72). Aristotle had discussed soul as the principle of activities following on the nature of the living substance, but Aquinas argued that the soul must be a participating principle of existence (ST, I' , q. 3, a. 4; Wippel 2003, 8). Aquinas' synthesis of Aristotelian hylomorphic theory with aspects of Neoplatonism was brought to light in the mid-twentieth century by the work of Fabro, Gieger and others (Fay 1973). Fabro wrote, "It is from the concept of esse as ground-laying first act that Thomas develops his own notion of participation and his entire metaphysics. (Fabro 1974, 463).”

We should not underestimate the place of Thomistic participation in completing Aristotelian anthropology (Annice 1952, 49). Bazan wrote that Aquinas' metaphysics "provides the ultimate foundation of his anthropology, namely the real distinction between esse and essentia and the philosophical theory of creation as causation of the finite act of being (esse) by an Infinite Being (Esse subsistens) (1997, 114).” Sweeney (1999, 145) has extolled "the true depth and uniqueness of (Aquinas') anthropology”. And Fabro insisted that Aquinas' dialectic of participation was "the hermeneutic key of the originality of Thomism" (1969, xxxiii).

\subsection{The convertibility of truth and goodness underpins the participatory view of rationality as an essential property}

TMP holds that both the essence of human being, and rationality as an essential property of that essence, are actualized on a common ground of participated being mediated by the actus essendi of the soul sharing in being from an Infinite Source. That rationality is an essential property of human nature is from Aristotle: "as each thing is in respect of existence, so it is in respect of truth" (Aristotle Metaphysics, 993b); and Aquinas, "that there is the same disposition of things in goodness and in being." $\left(\mathrm{ST}, \mathrm{I}^{\mathrm{a}}-\mathrm{II}^{\mathrm{ae}}\right.$, q. 18, a. 1) At the core of this argument is the understanding of how the transcendentals of truth and goodness are equivalent to being: "...being, the true, the one, and the good are such that by their very 
nature they are one in reality. Therefore, no matter where they are found, they are really one. (QDdV, q. 1, a. 1, ad 5; cf ST, I ${ }^{\mathrm{a}}$, q. 16, a. 3)

On the basis of the identity and convertibility of the transcendentals of goodness and truth with being, though they differ conceptually, TMP offers a reasoned understanding of how an embodied intellectual substance, grounded in subsistent Being, can know beings. It is a reasoned insight, not purporting to be a complete explanation of how we know, but one nevertheless that, as we shall see, points to rationality as an essential property of human nature, and therefore integral to human fulfilment.

Aertsen $(2007,11)$ notes,

Aquinas's argument for the convertibility of "true" and "being" draws a parallel to the convertibility between "good" and "being," which he had discussed earlier in the Summa (q. 5,1 and 5,3) [...] as good adds to being the notion of desirable, so the true adds a relation to the intellect.

The Thomistic understanding is that intellectual operations are directly a consequence of the degree of participation by the human essence in the act of being (Carreno 2015, 375). A Thomistic metaphysics of participation understands truth and goodness as transcendentals in a universal ground of being which is the ground and foundation of other transcendental categories (te Velde 2015, 764).

Rational operations are themselves participated powers. We understand:

...by means of participated species arising from the influence of the Divine light, shared by the soul as by other separate substances;...for God is the author of the influx of both of the light of grace and of the light of nature. ST, $\mathrm{I}^{\mathrm{a}}$, q. 89.

Specifically the active intellect is a participated power, not a formal or constitutive power (Fabro 1950, 272-273). This is of course radically different from both nonreductive and the classic hylomorphic views. 


\subsection{We are rational by nature, we don't just carry out rational behaviours}

In common, both TMP and NRP recognize the prerequisite implication of matter in all mental activity. TMP proposes, as does NRP, that intellectual operations of the embodied subject require but are not reducible to the biological. However, advocates of NRP see rationality as characterised by specific behaviours and operations such as agency, cognitive processing, reasoning, executive control, decision making, and intentional goal election (Gazzaniga 2011). Cognitive processes constitute "the slow road", in contrast to impulse driven "fast" responses (Haidt 2001). Mental intentions, consciousness, qualia, self-awareness, while inexplicable, are facets of rationality (Hauser 2006). Within such an approach, the intelligence and indeed "rationality" of animals may be studied (Edwards and Pratt 2009; Hemingway et al 2017).

While there is a legitimate place for reductive methods in biology (Kaiser 2015), by approaching rationality in this way, nonreductive materialist and emergent rationality accounts are open to the charge that they are reductive of the very notion of rational. The subjective, biophysical, descriptive, or measurable, becomes a substitute for rationality itself.

TMP holds that rationality is manifested in processes and subjective experiences but it may not be reduced to them. Ultimately the hylomorphic and Thomistic view is that we are rational because we have a human nature. We are not human because we are capable of abstract thought and because we have free will. We think and are free because we are human beings - existence is prior.

The reason therefore why Socrates understands is not because he is moved by his intellect, but rather, contrariwise, he is moved by his intellect because he understands... this particular man understands, because the intellectual principle is his form. ST, $\mathrm{I}^{\mathrm{a}}$, q. 76, a. 1 .

The human essence (and the essential characteristic of rationality) is actualised by the soul as inherent principle of life, unity and function. 
Because rationality is understood as an essential property, TMP offers a more coherent account than that offered by NRP which reduces rationality to process and experience, and fulfilment to the subjective.

TMP understands that the rational operations of human nature, the capacity to know reality and to make choices, are not reducible to processes of reasoning, or to consciousness, qualia or other subjective manifestations. They are unique to human beings as essential properties. Nature is manifested in operations of intellect and will, and also in subjective experience, but may not be reduced to them.

Within this view, questions about the hard problem of consciousness, have less significance. Williams (2004) points out that Aquinas viewed consciousness as a consequence of man's rational nature, not constitutive of it. The life of the mind is real with a subjective aspect, within both NRP and TMP, but from the perspective of TMP, the subjective is not causal of human existence, it is a consequence. A paradigm of participation thus potentially clarifies the notion of consciousness.

\subsection{An enriched account of causality}

The coherence of the TMP account hinges on an enriched grasp of constituting causation. The emphasis in contemporary Anglo-American Thomistic hylomorphism in the work of Feser (2005) and Madden (2013) is on formal causality. In contrast TMP allows a balanced understanding of the roles of efficient and formal causality. TMP looks to formal causality of the soul as a participated principle of life, unity and rational function, but also to the efficient causation effected by participation in being (DE, IV, 80) to account for the the "coming to be" of intelligent substances, and thus is able to interrogate NRP on this matter of the efficient causality of intelligent substances: both TMP and NRP recognize the role of efficient causality in accounting for existence, although in NRP neurobiology is proposed as the efficient cause of emergent mental activity. An account of final causality is also possible once the essential operations of knowing and loving are ascribed to human nature. Human beings are therefore fulfilled in knowing reality and making choices accordingly. The fi- 
nal cause of human rationality according to TMP is the grasp of truth and the capacity to love freely.

Both formal and efficient causalities are at play in an adequate Thomistic critique of emergent rationality. The soul's act of being is independent of the body: "non dependens a corpore" (QDdA, q. 1); esse subsistens is the ultimate efficient cause. Wippel writes that contingent being (ens) "participates in esse subsistens, that is to say, in God, as in its efficient and exemplar cause" (Wippel 2003, 5). The human formal principle transcends its own embodiment as it derives from an immaterial source and is the object of efficient causation in its coming-to-be.

...it cannot be that existence itself is caused by the very form or quiddity of the thing (I mean as by an efficient cause), because then the thing would be its own efficient cause, and the thing would produce itself in existence, which is impossible. DE, IV.

Being is prior to form. Form cannot explain existence: "the intellectual principle is the form of man" (ST, $\mathrm{I}^{\mathrm{a}}$, q. 76, a. 1).The substantial form provides the act of being of the composite substance, and that act of being, as we have seen, is a participation in esse subsistens. Hence a hylomorphism that stops at formal causality is incapable of offering an understanding of the efficient causality of the intellectual principle.

\section{TMP offers more complete understanding of rationality because it better grasps the role of rationality in human fulfilment}

In the quotation above, Roger Scruton referred to the need for a "teleological metaphysics"; TMP offers just such an enriched landscape of human fulfilment as a direct consequence of rationality understood as a participated property. Rationality as an essential property of human nature - ordered to truth and to making choices on basis of truth, to know and to love -takes teleological priority over other possible ends. Human fulfilment depends directly on the right exercise of these powers: a tele- 
ological account of man becomes possible once to know and to love are understood as essential powers.

Now the proper operation of man as man is to understand; because he thereby surpasses all other animals. Whence Aristotle concludes (Ethic. x, 7) that the ultimate happiness of man must consist in this operation as properly belonging to him. ST, $\mathrm{I}^{\mathrm{a}}$, q. 76, a. 1.

We have seen that truth (that which is grasped by the intellect) and goodness (that which is worthy of love), each enjoy transcendental dependence on being. It is the convertibility of the transcendentals that underpins such an understanding of human fulfilment.

The end of man, therefore, is to arrive at the contemplation of truth. It is for this purpose, then, that the soul is united to the body, and in this union does man's being consist. SCG, 2.84 .

NRP however offers no such objective finality operating. There is no intrinsic means of viewing rationality other than as processes facilitating subjective consciousness. NRP can offer no non arbitrary method of prioritizing spiritual fulfilment over material fulfilment. Fulfilment is locked into a subjective paradigm that cannot demonstrate priority over the material: Scruton proposes that the world "be understood in two incommensurable ways, the way of science, and the way of interpersonal understanding." $(2014,34$.) The arbitrary nature of NRP is evident perhaps most of all in the growing scepticism that freewill may well be an illusion and cannot be proven in an NRP paradigm, but can be pragmatically worked around. (Nahmias et al 2014; Caruso 2019).

There being no agreement within the NRP paradigm on human nature (Murphy 2013) there can be no necessary pathway to human fulfilment. The terminus for such an anti-metaphysical stance is either the arbitrary or the subjective. Subjective and idealistic goals must compete in the same material category as self-serving, pleasure-seeking, and possession-oriented goals. Therefore it may be said that NRP offers an essentially diminished view of humanity that cannot prioritise truth and love 
over hamburgers and candy; it runs counter to human experience and the wisdom traditions across all cultures and must count against the validity of a physicalist or emergent understanding of rationality.

Note Karol Wojtyla's comment about the necessity of metaphysics if we are to defend the spiritual nature of man:

Metaphysics should not be seen as an alternative to anthropology, since it is metaphysics which makes it possible to ground the concept of personal dignity in virtue of their spiritual nature. John Paul II, 83.

Aquinas wrote, quoting Aristotle (Metaphysics, 993b 24-31): "that which is most being and most truth is the cause of being and truth for all other things (DSS, 3. 15)." Without a ground of being, a ground of truth is difficult to demonstrate, and without this, the very nature of the rationality itself cannot be defined. Haldane notes the importance of a ground of being. He notes Heidegger's purpose to show 'how being embedded in the world is a precondition of our mindedness in general (Dasein)' (196). And although he critiques Heidegger's conclusions with reference to Christianity, he supports the view that a ground of being is necessary for a ground of truth (Haldane 1991, 196ff). Te Velde writes:

Following what Aquinas regarded as a genuine Aristotelian way of reasoning (cf. book II of the Metaphysics) these common features of all things - in particular their being and goodness - must be reduced to one common cause which has the fullness of being: ipsum esse. te Velde 2015, 764.

Furthermore, man's very capacity for self-giving love observes the same self-diffusion as found in the Primary act of being, precisely because it is a participation in being itself. "It is the nature of every actuality to communicate itself as far as possible (DP, 2.1)." Man is fulfilled in giving of himself, not at a material level where one is diminished in giving, but at the transcendent level of the person. Aquinas, from his first writings, viewed ens "not simply essentia or esse; rather it is the selfgivenness in act of their synthesis (Fabro 1966, 403). 
So ultimately man's very capacity for, and fulfilment in, self-giving love, may be shown to derive from participation in esse subsistens, 'to think of esse as the sheer act of giving oneself away... (Schindler 2005, 19).

This raises a further field of enticing exploration: that rationality is in fact ordered to relationships of love between persons: "the man who makes himself open to all being, in its wholeness and in its Ground, and becomes thereby a 'self', who is truly a person." (Horvat, 2017, 145). Walker offers philosophical arguments, developed from a communitarian Thomistic perspective, for the view that integral to rationality are loving relationships: that human persons by their very nature are fulfilled in personal loving relationships (2004). If truth-choosing-love be the highest operation of rationality then, by its participation in esse subsistens, the soul is a participating principle in the capacity to love wisely. Exploring a little more deeply, it may be argued that to love wisely in human experience is to love, first of all, other persons, and therefore we have insight into the Love in which we participate, and which, as we are persons, must first love us. Indeed a metaphysics of participation suggests, "that man could not be oriented toward union with God by the innate drive of his spirit unless there were some kind of profound ontological affinity or similitude.” (Norris Clarke 1981, 516)

As being, person, rationality and love are intrinsically related concepts within Thomistic metaphysics, it may be argued that the Being in which human beings participate may be understood as a personal love. Norris Clarke writes $(1992,616)$ of "person as the highest mode of being", quoting Aquinas (ST I ${ }^{\mathrm{a}}$, q. 29, a. 3): "person is that which is most perfect in all of nature". In such a vision, human beings find fulfilment most of all in the experience of interpersonal love.

\section{Conclusion}

In this paper I have proposed that Thomistic metaphysics of participation leads to conclusions about the nature of rationality and pathways for human fulfilment richer than is possible in a nonreductive physicalist philosophy of mind. I suggest that without such a metaphysical approach 
the conclusions about the nature of rationality and human fulfilment will be significantly impoverished. Furthermore, this approach founded on a metaphysics of participation contrasts significantly with the preferred lines of argument and demonstration in current Anglo-American hylomorphic philosophy of mind. I suggest that further study is advisable to reveal ways of integrating TMP with this current Aristotelian hylomorphic emphasis on formal causation. Study also could also fruitfully build on the work of Norris Clarke, Woytyla, and others, to explore human fulfilment founded on interpersonal relationships of love with a view to demonstrating its relevance to contemporary philosophy of mind.

\section{References}

Aertsen, Jan A. 2007. “Is truth not a transcendental?” In Wisdom's apprentice, edited by Peter A. Kwasniewski, 3-12. Washington: The Catholic University of America Press.

Annice, M. 1952. "Historical sketch of the theory of participation," The New Scholasticism 26: 49-79.

Aquinas, St. Thomas. 1965. De ente et essentia, edited by Joseph Kenny OP. Available at: https://isidore.co/aquinas/DeEnte\&Essentia.htm

Aquinas, St. Thomas. De potencia Dei, (reprint of 1932), edited by Joseph Kenny OP. Available at: https://isidore.co/aquinas/SubstSepar.htm

Aquinas, St. Thomas. De substantiis separatis, edited by Joseph Kenny OP. Available at: https://isidore.co/aquinas/SubstSepar.htm

Aquinas, St. Thomas. Quaestiones disputatae de anima, edited by Joseph Kenny OP. Available at: https://isidore.co/aquinas/QDdeAnima.htm

Aquinas, St. Thomas. Questiones disputatae de veritate, edited by Joseph Kenny OP. Available at: https://isidore.co/aquinas/QDdeVer.htm

Aquinas, St. Thomas. 1955-1957. The Summa Contra Gentiles, edited by Joseph

Kenny OP. New York: Hanover House. Available at: https://isidore.co/aquinas/ ContraGentiles.htm

Aquinas, St. Thomas. 2017. The Summa Theologica, translated by Fathers of the English Dominican Province. Online edition. Available at: https://www. newadvent.org/summa/

Aristotle, Metaphysics, translation by W.D. Ross. Available at: http://classics.mit. edu/Aristotle/metaphysics.8.viii.html 
Bazán, Bernardo Carlos. 1997. “The human soul: form and substance? Thomas Aquinas' critique of eclectic Aristotelianism." Archives d'histoire doctrinale et littéraire du Moyen Âge, 95-126.

Carreño, Juan Eduardo. 2015. "From self movement to esse: the notion of life and living being in Thomas Aquinas," Angelicum 92 (3): 347-376.

Caruso, Gregg D. (2019). "Free will skepticism and its implications: an argument for optimism." In Free will skepticism in law and society: challenging retributive justice, Chapter 3. Cambridge: Cambridge University Press.

Chalmers, David. 1996. The Conscious Mind. Oxford: Oxford University Press.

De Haan, Daniel. 2018. "The interaction of noetic and psychosomatic operations in a Thomist hylomorphic anthropology," Scientia et Fides 6 (2): 1-29. DOI: http://dx.doi.org/10.12775/SetF.2018.010.

Edwards, Susan C., \& Pratt, Stephen C. 2009. "Rationality in collective decisionmaking by ant colonies.” Proceedings of the Royal Society B: Biological Sciences 276 (1673): 3655-3661.

Fabro, Cornelio. 1950. La nozione metafisica di partecipazione secondo san Tommaso d'Aquino. Soc. Ed. Internazionale.

Fabro, Cornelio. 1966. "The transcendentality of ens-esse and the ground of metaphysics.” International Philosophical Quarterly 6 (3): 389-427.

Fabro, Cornelio. 1969. "Premessa.” In Esegesi Tomistica, xxxiii. Roma: Libreria Editrice della Pontificia Università Lateranense.

Fabro, Cornelio. 1970. "Platonism, Neo-Platonism and Thomism: Convergencies and Divergencies.” Neo-Scholasticism 44: 69-100.

Fabro, Cornelio. 1974. “The Intensive hermeneutics of Thomistic philosophy: The notion of participation.” Review of Metaphysics 27: 451-457.

Fay, Thomas A. 1973. "Participation: The Transformation of Platonic and Neoplatonic Thought in the Metaphysics of Thomas Aquinas.” Divus Thomas 50-64. Feser, Edward. 2005. Philosophy of mind: A short introduction. London: Oneworld. Gazzaniga, Michael S. 2011. Who's in charge? free will and the science of the brain. New York: HarperCollins.

Graybiel, Ann M., \& Smith, Kyle S. 2014. "Good habits, bad habits.” Scientific American 310 (6): 38-43.

Haidt, Jonathan. 2001. "The emotional dog and its rational tail: a social intuitionist approach to moral judgment.” Psychological review 108 (4): 814-834.

Haldane, John. 1991. “Incarnational anthropology.” Royal Institute of Philosophy Supplements 29: 191-211.

Hauser Marc. 2006. Moral minds. New York: Harper Collins. 
Hemingway, Claire T., Ryan, Michael J., \& Page, Rachel A. 2017. "Rationality in decision-making in the fringe-lipped bat, Trachops cirrhosus.” Behavioral Ecology and Sociobiology 71 (94): 1-10.

Horvat, Sasa. 2017. “Neuroscientific findings in the light of Aquinas' understanding of the human being." Scientia et Fides 5 (2): 127-153. DOI: http://dx.doi. org/10.12775/SetF.2017.021.

Jeffreys, Derek S. 2005. “A counter-response to Nancey Murphy on non-reductive Physicalism." Theology and Science 3 (1): 84-87.

Kaiser, Marie I. 2015. Reductive explanation in the biological sciences. Springer International Publishing.

John Paul II (1998) Fides et ratio. Vatican City: Polyglotta Vaticana.

Kim, Jaegwon. 1989. “The Myth of Nonreductive Materialism.” Proceedings and Addresses of the American Philosophical Association 63 (3): 31-47.

Knowles, Jonathan. 1999. "Physicalism, teleology and the miraculous coincidence problem,” The Philosophical Quarterly 49(195): 164-181.

Leite, Diego Azevedo. 2018. “Michael Gazzaniga's Neuro-cognitive Antireductionism and the Challenge of Neo-mechanistic Reduction.” Rivista internazionale di Filosofia e Psicologia 9 (2), 109-126.

Madden, James. 2013. Mind, Matter, and Nature: A Thomistic Proposal for the Philosophy of Mind. Washington DC: Catholic University of America Press.

Mróz, Mirosław. 2018. "Physiological and Psychological Foundation of Virtues: Thomas Aquinas and Modern Challenges of Neurobiology." Scientia et Fides 6 (2): 115-128. DOI: http://dx.doi.org/10.12775/SetF.2018.019.

Mullins, Andy. 2016. "Philosophical prerequisites for a discussion of the neurobiology of virtue.” Ethical perspectives 23 (4): 689-708.

Murphy, Nancey. 1998. "Non-reductive Physicalism: Philosophical Issues.” In Whatever Happened to the Soul? Scientific and Theological Portraits of Human Nature, edited by Brown, W.S., Murphy, N.C., \& Malony, H.N. Fortress Press.

Murphy, Nancey, 2009. “Is ‘Nonreductive Physicalism' an Oxymoron?” Metanexus Institute 1-14. Available at: http://web.missouri.edu/ segerti/1050H/docs/ MurphyNonreductive.pdf

Murphy N. 2013. “Nonreductive Physicalism.” In Encyclopedia of Sciences and Religions, edited by Anne L.C. Runehov, Lluis Oviedo. Dordrecht: Springer.

Nahmias, Eddy, Shepard, Jason, \& Reuter, Shane. 2014. “It's OK if 'my brain made me do it': People's intuitions about free will and neuroscientific prediction.” Cognition 133 (2): 502-516.

Norris Clarke, W. 1981. “The natural roots of religious experience.” Religious Studies 17 (4): 511-523. 
Norris Clarke, W. 1992. "Person, Being, and St. Thomas.” Communio 19 (4): 616. Norris Clarke, W. 1995. Explorations in Metaphysics. Southbend: UND Press.

Oleksowicz, Michał. 2018. "In search of the person. Towards a real revolution.” Scientia et Fides 6 (1): 229-262. DOI: http://dx.doi.org/10.12775/SetF.2016.008.

Pasnau, Robert. 1998. “Aquinas and the content fallacy.” The Modern Schoolman 75 (4): 293-314.

Pontifical Academy of Sciences. 2012. Neurosciences and the human person: new perspectives on human activities. Proceedings of the Working Group 8-10 November 2012, edited by A. Battro, S. Dehaene, W. Singer. Scripta Varia 121. Vatican City.

Rziha, John M. 2009. Perfecting human actions. St Thomas Aquinas on human participation in eternal law. Washington: Catholic University of America.

Schindler, D.C. 2005. "What's the difference? On the metaphysics of participation in a Christian context." The Saint Anselm Journal 3 (1): 1-27.

Scruton, Roger. 2014. The Soul of the World. Woodstock: Princeton University Press.

Sweeney, Michael J. 1999. "Soul as substance and method in Thomas Aquinas' anthropological writings.” AHDLMA 66: 143-187.

Tabaczek, Mariusz. 2016. “Emergence and Downward causation reconsidered in terms of the Aristotelian-Thomistic view of causation and Divine action. Scientia et Fides 4 (1): 115-149. DOI: http://dx.doi.org/10.12775/SetF.2016.010.

te Velde, Rudi. 2015. “Aquinas's Aristotelian science of metaphysics and its revised Platonism." Nova et Vetera 13:3: 743-764.

Tiehen, Justin. 2019. "How Counterpart Theory saves nonreductive physicalism." Mind 12.

Van Gulick, R. 2001. "Reduction, emergence and other recent options on the mind/body problem. A philosophic overview.” Journal of Consciousness Studies 8 (9-10): 1-34.

Walker, Adrian J. 2004. "Personal singularity and the communio personarum: A creative development of Thomas Aquinas' doctrine of esse commune." Communio: International Catholic Review 31: 457-479.

Williams, Thomas D. 2004. "What is Thomistic Personalism?” Alpha Omega 7 (2): 163-197.

Wilson, Jessica. 2015. “Metaphysical emergence: Weak and strong.” Metaphysics in contemporary physics 251:306-352.

Wippel, John F. 2003. "Metaphysical foundations for Christian humanism in Thomas Aquinas." In Congresso Tomista Internazionale (21-25 September 2003), 4-18. Roma. 
